\title{
A comprative study of Ksharkarma and Cryo Surgery in the Managment of Arsha (Haemorrhoids)
}

\author{
Research Article
}

\author{
Anant Kumar V Shekokar ${ }^{*}$, Kanchan M.Borkar ${ }^{2}$ \\ 1. Reader \& HOD, 2. Lecturer, \\ Department of Shalya tantra, Ayurved College Rahuri.
}

\begin{abstract}
According to Ayurveda Arshas is mentioned in the heading of Maharogas because it is Dirghakalanubandhi (chronic) and Dushcikitsya (hard to treat) in nature and involves the Marma. Arsha occurs in Gudabhaga (anal region) which is a Marma and the disease is well known for its chronicity and difficulty to treat \& hence a clinical study was carried out to compare the effects of Ksharkarma \& cryosurgery. The present study was designed into 2 groups and 30 patients are studied in each group. The results were statistically analyzed and the results have shown that the Ksharkarma therapy is more effective in comparision with the cryosurgery.
\end{abstract}

Keywords- Hemorrhoids, Ksharkarma, cryosurgery, Arsha, Pratisaran.

\section{Introduction}

Arhsas is one of the maharogas mentioned in Ayurveda. It occurs in the anal region. It is of two types. They are sahaja and kalakruta. They arise from three sites. They are meda, mamsa and tvak. The disease is considered as haemorrhoids in the present day (1).

Hemorrhoids are enlarged veins located in the lower part of the rectum and the anus. The veins become enlarged because of the increase in the pressure to the particular veins especially because of liver disorders, hard stools, pregnancy etc. Haemorrhoids can be internal or external. Internal haemorrhoids are located in the rectum and can be felt only bleeding

*Corresponding Author:

Anant kumar V Shekokar,

HOD and Reader,

Department of Shalya Tantra,

Ayurved college, Rahuri, 413706.

Maharashtra, India.

Email-dranantkumarshekokar@gmail.com during defaecation. They may be visible when they protrude out of the anal canal. External haemorrhoids are formed in the skin around the anus. The treatment of the haemorrhoids include high fibre diet to facilitate easy bowel movement. Non operative therapies include the sclerotherapy, rubber band ligation, heat coagulation and cryosurgery. Cold temperatures are used to obliterate the veins in the cryosurgery. This causes scarring of the veins (2).

Sushruta, the father of Indian surgery, has mentioned four line treatments for the management of Arshas.

1. Bhesaja Chikitsa (Medical treatment)

2. Kshara Karma (Caustic cautery)

3. Agnikarma (Thermal cautery)

4. Shastrakarma (Surgery).

Of the four Ksharakarma, is one of the easiest and minimal invasive techniques, and is well tolerated by many of the patients. There is minimal interference in patient's routine. It is also 
effectively administered to age patients and those unfit for work. It involves the application of the Kshara (Caustic material) prepared by the plants and is applied directly to the haemorrhoids (3).

The present study is planned to know the efficacy of the Ksharakarma and cryosurgery in the management of the Arsha (haemorrhoids/ piles).

Materials and methods:

Plant materials used:

In the present study, Kshara will be prepared using Panchanga (whole plant) of plants given below with Sushrutokta Kshara-pak method (Table 1) (4)

Table 1: Showing the plants used for the preparation of the Kshara.

$\begin{array}{lll}\text { Drug name } & \text { Botanical name } & \text { Family } \\ \text { Kutaja } & \text { Holarrhena antidysenterica } & \text { Apocynaceae } \\ \text { Palaash } & \text { Butea frondosa } & \text { Leguminoseae } \\ \text { Ashwakarna } & \text { Dipterocarpus turbinatus } & \text { Dipterocarpaceae } \\ \text { Paribhadrak } & \text { Erythrina vaviegata } & \text { Leguminoseae } \\ \text { Bibhitak } & \text { Terminalia belerica } & \text { Combrataceae } \\ \text { Aaragwadh } & \text { Cassia fistula } & \text { Leguminoseae } \\ \text { Tilwak (Lodhra) } & \text { Symplocos recemosa } & \text { Symplocaceae } \\ \text { Arka } & \text { Calotropis procera } & \text { Asclepiadaceae } \\ \text { Snuhi } & \text { Euphorbia neriifolia } & \text { Euphorbiaceae } \\ \text { Apaamarga } & \text { Achyranthes aspera } & \text { Amaranthaceae } \\ \text { Paatala } & \text { Stereospermum suaveolens } & \text { Bignoniaceae } \\ \text { Naktamaal (Karanja) } & \text { Pongamia pinnata } & \text { Leguminoseae } \\ \text { Vrushak (Vaasa) } & \text { Adhatoda vasica } & \text { Acanthaceae } \\ \text { Kadali } & \text { Musa paradisiacal } & \text { Scitaminaceae } \\ \text { Chitrak } & \text { Plumbago zeylanica } & \text { Plumbaginaceae } \\ \text { Putik (Cheerbilva) } & \text { Holoptelia integrifolia } & \text { Ulmaceae } \\ \text { Indravruksha (Devdaar) } & \text { Cedrus deodara } & \text { Pinaceae } \\ \text { Aasphot (Saariva) } & \text { Hemidesmus indicus } & \text { Asclepiadaceae } \\ \text { Ashwamaar (Kaner) } & \text { Nerium indicum } & \text { Apocynaceae } \\ \text { Saptachhada (Saptaparna) } & \text { Alstonia scholaris } & \text { Apocynaceae } \\ \text { Agnimantha } & \text { Premna mucronata } & \text { Verbenaceae } \\ \text { Gunja } & \text { Abrus precatorius } & \text { Leguminoseae } \\ \text { Koshataki } & \text { Cuffa acutangula } & \text { Cucurbitaceae } \\ & & \\ & & \end{array}$

Other materials used:

Stove, Large enamel vessel, Ladle and Match box or gas lighter.

\section{Prepation of Pratisaraniya Kshara (5):}

Panchanga of above plants are collected on auspicious day from the plants growing in the hygienic places as mentioned in the texts of Ayurveda. They are then cut down into pieces and let dried naturally, protected from direct sunlight and wind. When they are well dried, they are burnt to ash in a big vessel. When they are well burnt, the white ashes are separated.

The white ashes are then mixed with water ( 1 part ashes is mixed with 6 parts water) and filtered with fine line for 21 times (1 time per day). The product of above process was coffee coloured water which was then put in a large enamel vessel and boiled by gently agitating it 
with a ladle. Till the saturated water appears to Achchha (pure), Rakta (reddish), Pichchhila (sticky) and Tikshana (corrosive). It should be let dried to derive a paste like product called as "Pratisaraniya Kshara".

\section{Properties of Kshara:}

\begin{tabular}{|l|l|}
\hline Rasa & Katu \\
\hline Virya & Ushna \\
\hline Varna & Shukla \\
\hline Guna & $\begin{array}{l}\text { Saumaya, Tikshna, } \\
\text { Aganeya }\end{array}$ \\
\hline Doshaghanata & Tridoshghanta \\
\hline Karma & $\begin{array}{l}\text { Dahan, Pachan, Darana, } \\
\text { Vilayan, Shodahan, } \\
\text { Ropana, Shoana, } \\
\text { Stambhana, Lekhana. }\end{array}$ \\
\hline
\end{tabular}

Because of the caustic nature of the Kshara, the enlarged masses of the haemorrhoids get sclerosed, cause the chemical burn and destroy the haemorrhoids.

\section{Clinical study:}

\section{Examination of Patients:}

Each patient was throughly examined by detailed Proforma designed for the present study on Arsha. Patients were examined under the following headings.

- According to symptoms / history

- Per rectal (Digital)

- Proctoscopy

- Sigmoidoscopy - If required

- Colonoscopy - If required

\section{History of the Patients:}

Complete history of the patient with presenting complaints like protrusion of mass per rectum, discharge, pain, duration and bowel habit was noted.

History of associated disease like tuberculosis, diabetes mellitus, cardiac disease, malignancy, chronic renal failure etc. was tried to trace out to exclude the condition from the present study.

History of a previous treatment particularly previous surgery, number of surgeries, type of operative procedure adopted and also family history, occupation, personal history and dietetic habits were taken into consideration to relation to the occupation, recurrence of the disease and habit etc.

\section{Systemic Examination:}

Each patient was examined systemically under different systems like digestive, cardio-vascular, respiratory and genitourinary. If any system was found abnormal, then specific investigations were used to irm inclusion or exclusion criteria

\section{Local Examination:}

It was done under following headings with prior consent from patient.

a) Inspection

Firstly, patient was instructed to lie down in lithotomy position. After this a detail examination of perianal region was carried out and positive findings were noted down on the case paper. Patient was asked to strain if prolapsed pile mass is not visualised.

b) Palpation

The palpation of the perianal region or the pile mass was done to determine the degree of severity of tenderness in that region.

\section{c) Digital rectal examination:}

It was carried out with well lubricated gloved finger and the severity of spasm of sphincter muscle, character of pile mass, any other growth etc. were examined and documented on paper.

\section{Investigations:}

- C.B.C.

- Urine and Stool macro \& micro examinations

- Biopsy (If required) 
- H.I.V.

- $\mathrm{HbsAg}$

- Investigations required for Physician $\&$ Anaesthesia fitness for surgery.

\section{Clinical study:}

\section{Number of patients:}

60 patients fulfilling the criteria for the diagnosis of disease were registered from the O.P.D. of Dept. of Shalyatantra of Ayurved College Hospital, Rahuri, for the present study irrespective of their age, sex, religion etc. They were divided into two groups. For Group A patients Ksharakarma was done and for the Group $B$ patients Cryosurgery was done as mentioned in the standard literature of the procedure.

Written consent was taken from patients before including in study for anaesthesia operative procedures, various time to time investigations and examining procedures like digital examination and proctoscopy.

\section{Selection Criteria:}

\section{Inclusive criteria:}

- Patients presenting with Nidan, Lakshana \& Samprapti of Arsha.

- Patients presenting with causes, clinical features \& etiopathology of Piles.

- Indications of Kshara \& Cryosurgery as stated in literature.

- Diagnosis done with local examination.
- i.e. Inspection

- Palpation

- Digital Examination

- Proctoscopy

- Grade I \& Grade II internal piles.

- Physically fit for all Surgical, Para surgical procedures \& anesthesia.

- Uncomplicated piles.

\section{Exclusive criteria: -}

- Grade III \& Grade IV prolapsed piles

- Contraindications of Kshara \& Cryosurgery as stated in literature

- Piles associated with perianal abscess, fissure, fistula etc.

- Rectal prolapse

- Crohn's disease

- Ulcerative colitis

- Rectal polyp

- Condyloma

- Anal epithelioma

- Carcinoma of rectum

- Proctitis

- Piles with complications i.e. ulcerated, thrombosed, fibrosed, infected etc.

- Medico physically unfit patients.

Materials and details of the procedures done:

Both procedures (Ksharakarma and Cryotherapy) were carried out under Spinal anaesthesia under expert Anaesthetist guidance and monitoring.

Table 2: Showing the procedures

\begin{tabular}{|l|l|l|}
\hline & Ksharakarma (Group-A) & Cryosurgery (Group B) \\
\hline Instruments used & $\begin{array}{l}\text { Proctoscope, Darvimukh } \\
\text { shalaka (Scoop), Prepared } \\
\text { Kshara, Nimbu swaras, Allis } \\
\text { tissue forceps, Artery forceps }\end{array}$ & $\begin{array}{l}\text { Proctoscope, Cryosurgery } \\
\text { unit }\end{array}$ \\
\hline $\begin{array}{l}\text { Pre operative procedure } \\
\text { adopted }\end{array}$ & $\begin{array}{l}\text { NBM overnight } \\
\text { Soap water enema 3-4 hours } \\
\text { prior to procedure was } \\
\text { administered }\end{array}$ & $\begin{array}{l}\text { NBM overnight } \\
\text { prior to procedure was } \\
\text { administered }\end{array}$ \\
\hline Operative procedure & $\begin{array}{l}\text { Patients were kept in } \\
\text { Lithotomy position. }\end{array}$ & $\begin{array}{l}\text { Patients were kept in } \\
\text { Lithotomy position. }\end{array}$ \\
\hline
\end{tabular}




\begin{tabular}{|l|l|l|}
\hline & $\begin{array}{l}\text { Cleaning \& draping of the } \\
\text { part. } \\
\text { Operative procedure was } \\
\text { carried out as guided in } \\
\text { literature }\end{array}$ & $\begin{array}{l}\text { Cleaning \& draping of the } \\
\text { part. } \\
\text { Operative procedure was } \\
\text { carried out as guided in } \\
\text { literature }\end{array}$ \\
\hline Duration & $\begin{array}{l}1-1.5 \text { minutes (100 Matra } \\
\text { kala) }\end{array}$ & $\begin{array}{l}3-5 \text { minutes depending upon } \\
\text { the vascularity of the part }\end{array}$ \\
\hline Completion of procedure & $\begin{array}{l}\text { Pakwa jambuphala like } \\
\text { appearance of pile mass }\end{array}$ & $\begin{array}{l}\text { Appearance of white frost } \\
\text { over the surface of pile mass }\end{array}$ \\
\hline $\begin{array}{l}\text { After completion of } \\
\text { procedure }\end{array}$ & $\begin{array}{l}\text { Dhavan with Nimbu swaras } \\
\text { Removal of cryoprobe when } \\
\text { active end was thawed }\end{array}$ \\
\hline
\end{tabular}

\section{Post operative care:}

- Sitz bath was given using Triphala kwath.

- Liquid diet started 6 hours after surgery.

- Patients were administered Inj. Cefuroxime $750 \mathrm{mg} \& \mathrm{Inj}$. Metronidazole $500 \mathrm{mg}$ for first 24 hours. Same kinds of tablets were given after patient started taking oral diet.

- Diclofenac injections and tablets were used to relieve pain.

- Duphalac syrup was given at night for softening of stool.

- Patients were discharged on $3^{\text {rd }}$ day after procedure.

Follow up days: $7^{\text {th }}, 14^{\text {th }}, 21^{\text {st }}$ and $30^{\text {th }}$ post operative day.

Observations and Results:

Table 3: Effect of the Ksharakarma on cardinal symptoms of Arsha in Group A

\begin{tabular}{|l|l|l|l|l|l|l|l|l|}
\hline \multirow{2}{*}{ Signs / Symptoms } & \multirow{2}{*}{$\mathbf{n}$} & \multicolumn{2}{|l|}{ Mean } & $\begin{array}{l}\text { Relief } \\
\text { \% }\end{array}$ & $\begin{array}{l}\text { S.D. } \\
+/- \\
\text { B.T. }\end{array}$ & $\begin{array}{l}\text { S.D. } \\
+/- \\
\text { A.T. }\end{array}$ & t & Result \\
\cline { 3 - 10 } Guda pida (Cutting pain) & 30 & 2.13 & 0.77 & $61 \%$ & 0.73 & 0.81 & 6.83 & H.S. \\
\hline Guda daha (Burning pain) & 30 & 1.87 & 0.70 & $62 \%$ & 0.68 & 0.79 & 6.10 & H.S. \\
\hline Rakta srava (Bleeding P/R) & 30 & 2.27 & 0.70 & $69 \%$ & 0.94 & 0.79 & 6.95 & H.S. \\
\hline Guda kandu (Itching) & 30 & 2.10 & 0.70 & $66 \%$ & 0.75 & 0.70 & 7.41 & H.S \\
\hline Bhramsha (Prolapse) & 17 & 0.94 & 0.47 & $52 \%$ & 0.24 & 0.51 & 3.41 & S \\
\hline Sparshasahatva (Tenderness) & 30 & 2.10 & 0.80 & $61 \%$ & 1.02 & 0.92 & 5.14 & S \\
\hline Shotha (Inflammation) & 28 & 2.29 & 0.96 & $57 \%$ & 1.08 & 1.03 & 4.66 & S \\
\hline Guda srava (Mucous discharge) & 30 & 1.93 & 0.50 & $74 \%$ & 0.94 & 0.73 & 6.57 & S \\
\hline
\end{tabular}

Criteria for assessment of overall symptoms:

1. Cured: Total relief in symptoms $75 \%$ to $100 \%$.

2. Markedly improved: $50 \%$ to $75 \%$ improvement from signs and symptoms is termed as markedly improved.

3. Improved: Improvement range in between $25 \%$ to $50 \%$ responded by patient in signs and symptoms is taken for improved.

4. Unchanged: The patients presenting less than 25\% improvement in their signs and symptoms are taken as unchange. 
Table 4: Effect of Cryosurgery on cardinal symptoms of Arsha in Group B

\begin{tabular}{|l|c|c|c|c|c|c|c|c|}
\hline \multicolumn{1}{|c|}{ Signs / Symptoms } & $\mathbf{n}$ & \multicolumn{2}{|c|}{ Mean } & $\begin{array}{c}\text { Relief } \\
\%\end{array}$ & $\begin{array}{c}\text { S.D. } \\
+/- \\
\text { B.T. }\end{array}$ & $\begin{array}{c}\text { S.D. } \\
+/- \\
\text { A.T. }\end{array}$ & T & Result \\
\cline { 3 - 6 } & & $\mathbf{B T}$ & $\mathbf{A T}$ & & & \\
\hline Guda pida (Cutting pain) & 30 & 2.10 & 1.00 & $56 \%$ & 0.88 & 0.87 & 4.85 & $\mathbf{S}$ \\
\hline Guda daha (Burning pain) & 30 & 2.13 & 0.87 & $59 \%$ & 0.60 & 0.87 & 5.70 & $\mathbf{S}$ \\
\hline Rakta srava (Bleeding P/R) & 30 & 2.00 & 0.83 & $60 \%$ & 0.98 & 0.91 & 4.76 & S \\
\hline Guda kandu (Itching) & 30 & 1.93 & 0.80 & $58 \%$ & 0.78 & 0.96 & 5.00 & S \\
\hline Bhramsha (Prolapse) & 24 & 0.96 & 0.38 & $62 \%$ & 0.20 & 0.49 & 5.34 & S \\
\hline Sparshasahatva (Tenderness) & 30 & 2.11 & 0.85 & $58 \%$ & 0.93 & 0.90 & 5.02 & S \\
\hline Shotha (Inflammation) & 28 & 2.04 & 0.82 & $59 \%$ & 0.99 & 0.94 & 4.67 & S \\
\hline $\begin{array}{l}\text { Guda srava (Mucous } \\
\text { discharge) }\end{array}$ & 30 & 1.93 & 1.57 & $20 \%$ & 0.82 & 1.07 & 1.48 & $\begin{array}{c}\text { N.S. at } \\
\mathbf{5 \%}\end{array}$ \\
\hline
\end{tabular}

$\mathrm{n}=$ Number of Patients, S.D = Standard Deviation, B.T= Before Treatment,

A.T $=$ After Treatment, $\%=$ Percentage, Cal. $=$ Calculated,

H.S = Highly Significant, N.S = Not Significant

Table 5: Percentage of relief on chief complaints.

\begin{tabular}{|l|l|l|}
\hline \multirow{2}{*}{ Chief Complaints } & \% of Relief \\
\cline { 2 - 3 } & Gr.A & Gr.B \\
\hline Guda Daha (burning pain) & $61 \%$ & $56 \%$ \\
\hline Guda Pida(Cutting pain) & $62 \%$ & $59 \%$ \\
\hline Bleeding P/R (Rakta Srava) & $69 \%$ & $60 \%$ \\
\hline Guda kandu (Itching) & $66 \%$ & $58 \%$ \\
\hline Bhramsha (Prolapse) & $52 \%$ & $62 \%$ \\
\hline Sparshasahatva(Tenderness) & $61 \%$ & $58 \%$ \\
\hline Shotha (Inflammation) & $57 \%$ & $59 \%$ \\
\hline Guda srava (Mucous discharge) & $74 \%$ & $20 \%$ \\
\hline
\end{tabular}

$\mathrm{n}=$ Number of Patients, S.D $=$ Standard Deviation, B.T $=$ Before Treatment,

A.T $=$ After Treatment, $\%=$ Percentage, Cal. $=$ Calculated,

H.S = Highly Significant, N.S = Not Significant

Table 6: Percentage of relief of KsharaKarmaa and Cryosurgery

\begin{tabular}{|l|l|l|l|l|}
\hline & \multicolumn{2}{|c|}{ Ksharakarma } & \multicolumn{2}{c|}{ Cryosurgery } \\
\hline Effect & No. of patients & Percentage \% & No. of patients & Percentage \% \\
\hline Cured & 7 & 23.33 & 4 & 13.33 \\
\hline Markedly improved & 21 & 70 & 15 & 50 \\
\hline Improved & 2 & 6.66 & 10 & 33.33 \\
\hline Unchanged & 0 & 0 & 1 & 3.33 \\
\hline Total & 30 & 100 & 30 & 100 \\
\hline
\end{tabular}




\section{Discussion and conclusion:}

Arshas is one of the maharogas arising from the rectum and the anal canal. It is characterized by the pain, itching and bleeding. It is caused by the enlargement of the veins of the anal canal. One of the widely used therapies in the treatment of the disease is Ksharakarma. So the present study is aimed at the comparative study of the effect of Cryosurgery and Ksharakarma.

The results obtained in the present study showed that Ksharakarma is highly effective in the management of the Arshas. Cryosurgery showed only significant results in the treatment. With the Ksharakarma procedure $23.33 \%$ got completely cured, $70 \%$ markedly improved and $6.66 \%$ improved, whereas with the Cryosurgery procedure $13.33 \%$ got completely cured, $50 \%$ got markedly improved, 33.33\% have got improved and $3.33 \%$ patients did not show any change in the condition. Thus the results have shown that the Ksharakarma is more effective in the management of the arshas when compared to the Cryosurgery.

\section{References:}

1. KashinathShashtri, Caraka samhita of Maharshi Agnivesha, $19^{\text {th }}$ edition, Varanasi, Chaukhamba Bharati Academy. 1997. p.417

2. http://www.emedicinehealth.com/ hemorrhoids/ article_em.htm\#hemorrhoid_overvi ew, dt 22-08-2012, time $6.14 \mathrm{pm}$

3. Ambikadatta, Sushruta samhita of Acarya Sushruta Dalhanacharya commentary, $11^{\text {th }}$ edition, Varanasi, Chaukhamba Sanskrit Samsthan. 1953, p.35

4. Ambikadatta, Sushruta samhita of Acarya Sushruta Dalhanacharya commentary, $11^{\text {th }}$ edition, Varanasi, Chaukhamba Sanskrit Samsthan. 1953, p.35

5. Ambikadatta, Sushruta samhita of Acarya Sushruta Dalhanacharya commentary, $11^{\text {th }}$ edition, Varanasi, Chaukhamba Sanskrit Samsthan. 1953, p.36 